\title{
A new species of Characidium (Characiformes: Crenuchidae) from small coastal drainages in northeastern Brazil, with remarks on the pseudotympanum of some species of the genus
}

\author{
Angela M. Zanata ${ }^{1}$ and Priscila Camelier ${ }^{2}$
}

Characidium samurai, a species of the family Crenuchidae apparently endemic to rio das Almas and rio Vermelho basins, Bahia, Brazil, is described. The new species is readily distinguishable from its congeners, except $C$. lanei, by having a dark lateral band along the head and body that is particularly broad from the rear of the head to the end of the caudal peduncle (1.5 or 2 scales wide) and by the absence of dark bars or blotches on the ventral half of the body. Characidium samurai differs from C. lanei by having the lateral band with straight borders overall (vs. lateral band with somewhat irregular borders due to blotches extending dorsally or ventrally), anal fin ii,7-8 (vs. ii,6), and 4 horizontal scale rows above the lateral line and 4 below (vs. 5/3). It further differs from congeners by a series of features, including isthmus completely covered by scales, lateral line complete with 34-37 perforated scales, 9 scales on the transversal line, 14 scale rows around the caudal peduncle, anal fin ii,7-8, and the absence of dark bars or spots on the fins, except by a faded dorsal-fin bar. The presence of pseudotympanum in four species of Characidium is discussed.

Characidium samurai, uma espécie nova de Crenuchidae aparentemente endêmica das bacias do rio das Almas e rio Vermelho, Bahia, Brasil, é aqui descrita. A espécie nova difere das demais espécies do gênero, exceto C. lanei, por apresentar uma faixa lateral escura ao longo da cabeça e corpo, particularmente larga desde área após a cabeça até final do pedúnculo caudal (largura de 1,5 ou 2 escamas) e pela ausência de barras ou manchas escuras na metade ventral do corpo. Characidium samurai difere de $C$. lanei por ter faixa lateral com bordas retas (vs. faixa lateral com bordas relativamente irregulares devido à presença de manchas projetando-se dorsal ou ventralmente), nadadeira anal ii,7-8 (vs. ii,6) e 4 séries de escamas acima da linha lateral e 4 abaixo (vs. 5/3). Difere ainda das congêneres por uma série de características, que inclui istmo completamente coberto por escamas, linha lateral completa com 34-37 escamas perfuradas, 9 escamas na linha transversal, 14 séries de escamas ao redor do pedúnculo caudal, nadadeira anal ii,7-8 e ausência de faixas ou manchas escuras nas nadadeiras, exceto por uma faixa inconspícua na nadadeira dorsal. A presença de pseudotímpano é discutida em quatro espécies de Characidium.

Key words: Characidiinae, Characidium bahiense, Freshwater fish, Neotropical region, Taxonomy.

\section{Introduction}

Characidium Reinhardt is the most diverse genus of the family Crenuchidae, with 56 valid species of small Neotropical fishes that are distributed from Argentina to Panama (Buckup, 2003; Graça et al., 2008; Silveira et al., 2008; Peixoto \& Wosiacki, 2013; Lujan et al., 2013; Netto-Ferreira et al., 2013). Characidium is currently considered to be a monophyletic group based on the presence of a black spot near the base of the middle caudal-fin rays, but the relationships within the genus are not completely resolved, possibly because of the high number of undescribed species and the absence of derived characters (Buckup, 1993a).

Two species of Characidium have been described from northeastern Brazil: C. bahiense Almeida from Arembepe, Bahia, and C. bimaculatum Fowler from Fortaleza, Ceará. Three other species were described from nearby drainages, C. fasciatum Reinhardt and C. lagosantense Travassos from the rio São Francisco basin and C. timbuiense Travassos from the rio Timbuí basin, a coastal drainage of Espírito Santo State. Based on the literature, only C. bahiense is

\footnotetext{
${ }^{1}$ Departamento de Zoologia, Instituto de Biologia, Universidade Federal da Bahia, Campus de Ondina. Rua Barão de Geremoabo s/n, 40170-290 Salvador, BA, Brazil. zanata.angela@gmail.com (corresponding author)

${ }^{2}$ Museu de Zoologia da Universidade de São Paulo. Caixa Postal 42494, 04218-970 São Paulo, SP, Brazil. pricamelier@gmail.com
} 
reliably documented to occur in rivers draining Bahia. A series of recent publications, including inventories and ecological studies in some of these rivers, revealed a broad occurrence of species identified as Characidium sp. (e.g., Sarmento-Soares et al., 2007, 2008, 2009; Sarmento-Soares \& Martins-Pinheiro, 2009; Cetra et al., 2010), C. cf. bahiense and C. cf. bimaculatum (e.g., Santos \& Caramaschi, 2007, 2011) or C. aff. timbuiense and C. aff. zebra (e.g., Burger et al., 2011; Cetra et al., 2011), attesting to the taxonomic difficulties regarding the identification of species in the genus. Collecting efforts performed in the last eight years in the costal drainages of Bahia have revealed various undescribed species of Characidium, including one described in the present study, apparently endemic to the small drainages of rio das Almas and rio Vermelho.

\section{Material and Methods}

Measurements and counts follow Buckup (1993b), except by the unbranched rays located near the posterior edge of the fins that were not included in the count of branched rays. Measurements were taken with a digital caliper to the nearest $0.1 \mathrm{~mm}$ and are expressed as percents of standard length (SL) for body parts and head length (HL) for parts of the head. Frequencies of counts are given in the text in parentheses after the respective characteristic, and an asterisk indicates values from the holotype. Observations of vertebrae, ectopterygoid teeth, branchiostegal rays, procurrent caudal-fin rays, ural bones, and some other osteologic observations were made only from cleared and stained (c\&s) paratypes that were prepared according to Taylor \& Van Dyke (1985). The number of c\&s specimens or the number of specimens that were directly preserved in alcohol without fixation in formalin (mol) is given after the total number of specimens. The sex of some specimens was confirmed by dissection. The pseudotympanum morphology was assessed by removal of the overlying skin, adipose tissue, and lateral-line nerve of alcohol-preserved specimens. Specimens utilized for comparative analysis are listed under 'Comparative material examined'. Institutional abbreviations are: MZUSP, Museu de Zoologia da Universidade de São Paulo, São Paulo; MNRJ, Museu Nacional, Rio de Janeiro, Rio de Janeiro; UFBA, Museu de Zoologia da Universidade Federal da Bahia, Salvador.

\section{Results}

\section{Characidium samurai, new species} Fig. 1

Holotype. MZUSP 108188, 46.6 mm SL, Brazil, Bahia, Piraí do Norte, rio do Peixe, tributary of rio das Almas, 134' $35^{\prime \prime} \mathrm{S}$
39²3'40”W, 177 m a.s.1., 13 Aug 2012, O. T. Oyakawa, A. M. Zanata, P. Camelier \& T. F. Teixeira.

Paratypes. All from Brazil, Bahia, rio das Almas basin: MZUSP 112385, 9, 1 mol, 25.4-42.7 mm SL, UFBA 7259, 7, 20.8-42.6 mm SL, collected with holotype. MNRJ 40727, 4, 31.6-39.2 mm SL, UFBA 5971, 9, 2 c\&s, 29.3-40.9 mm SL, Piraí do Norte, rio do Peixe, a tributary of rio das Almas, 1346’35"S 39²3'40”W, 177 m a.s.1., 8 Oct 2009, A. M. Zanata, P. Camelier, R. Burger \& A. B. A. Góes. MZUSP 111239, 5, 1 c\&s, 1 mol, 28.1-42.6 mm SL, Nilo Peçanha, rio das Almas, about10 km of Nilo Peçanha, 13³6'27.8'S 3908'38.8'W, 17 m a.s.1., 12 Aug 2012, J. L. Birindelli, F. C. Dagosta \& M. V. Loeb. UFBA 5726, 3, 26.4-31.3 mm SL, Piraí do Norte, small stream under bridge between Piraí do Norte and Gandú, $13^{\circ} 43^{\prime} 59^{\prime}$ 'S 39²4'20'W, 157 m a.s.1., 8 Oct 2009, A. M. Zanata, P. Camelier, R. Burger \& A. B. A. Góes. Rio Vermelho basin: UFBA 7258, 5, 27.9-34.0 mm SL, Taperoá, rio Sarapuí, at Pousada Paraíso das Ilhas, 13³0'05.2”S 3905'50.4”W, 24 m a.s.1., 12 Aug 2012, J. L. Birindelli, F. C. Dagosta \& M. V. Loeb.

Diagnosis. Characidium samurai can be distinguished from its congeners, except $C$. lanei Travassos, by the presence of a dark lateral band along the head and body that is particularly broad (1.5 or 2 scales wide) from the rear of head to the end of the caudal peduncle and by the absence of dark bars or blotches on the ventral half of the body. The new species differs from $C$. lanei by having the lateral band with straight borders overall (vs. lateral band with somewhat irregular borders due to blotches slightly extending dorsally or ventrally), absence of dark pigmentation around the insertion of the dorsal-fin rays (vs. presence), anal fin ii,7-8 (vs. ii,6), and 4 horizontal scale rows above the lateral line and 4 below (vs. 5/3). Characidium samurai further differs from congeners that occur in Brazilian rivers by having a complete lateral line (vs. incomplete in C. bahiense, C. interruptum Pellegrin, C. laterale (Boulenger), C. mirim Netto-Ferreira, Birindelli \& Buckup, C. nupelia Graça, Pavanelli \& Buckup, C. rachovii Regan, C. stigmosum Melo \& Buckup, and C. xavante Graça, Pavanelli \& Buckup), isthmus completely covered by scales (vs. isthmus naked or partially covered by scales in C. alipioi Travassos, C. boavistae Steindachner, C. crandellii Steindachner, C. declivirostre Steindachner, C. fasciatum, C. gomesi Travassos, C. grajahuensis Travassos, C. japuhybense Travassos, C. lauroi Travassos, C. macrolepidotum (Peters), C. oiticicai Travassos, C. schubarti Travassos, C. timbuiense, and C. vidali Travassos), 14 scales around the caudal peduncle (vs. 10 or 12 in $C$. bahiense, C. brevirostre Pellegrin, C. gomesi, C. heirmostigmata Graça \& Pavanelli, C. lagosantense, C. macrolepidotum, C. mirim, C. nupelia, C. occidentale Buckup \& Reis, C. orientale Buckup \& Reis, C. papachibe Peixoto \& Wosiacki, C. rachovii, C. serrano Buckup \& Reis, C. tenue (Cope), C. xanthopterum Silveira, Langeani, da Graça, Pavanelli \& Buckup, C. xavante, and C. zebra Eigenmann), and presence of adipose fin (vs. absent in C. mirim, C. nupelia, C. stigmosum, C. xavante and absent or reduced in C. vestigipinne Buckup \& Hahn). Characidium 

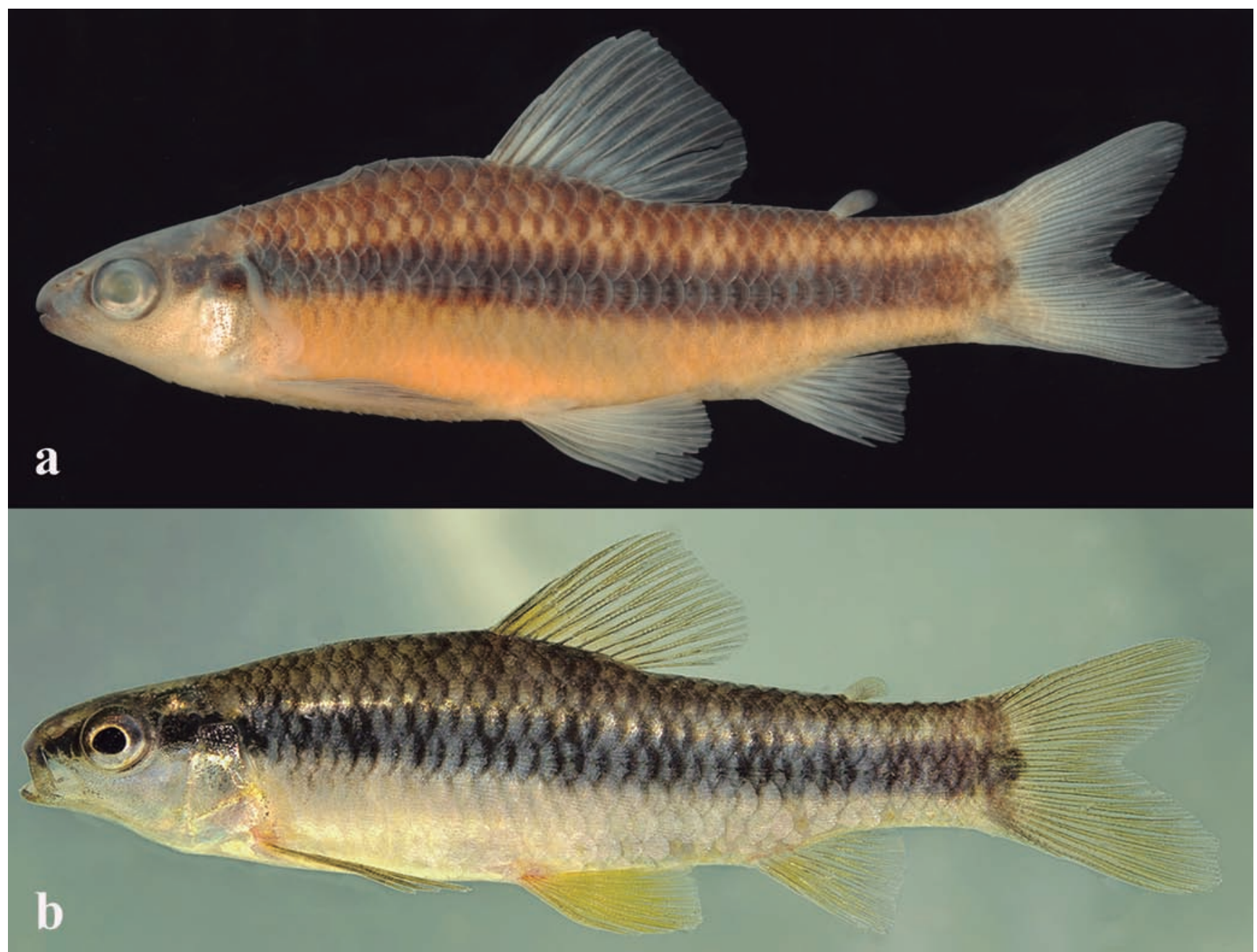

Fig. 1. Characidium samurai, holotype, MZUSP 108188, $46.6 \mathrm{~mm} \mathrm{SL}$, rio do Peixe, rio das Almas basin: (a) preserved specimen and (b) photographed live.

samurai can be further distinguished from congeners by the absence of dark bars or spots on the fins, except for a faded dorsal-fin bar (vs. presence of conspicuous dark bars or spots at least on one fin in C. alipioi, C. brevirostre, C. declivirostre, C. gomesi, C. grajahuensis, C. hasemani Steindachner, C. japuhybense, C. lauroi, C. macrolepidotum, C. occidentale, C. oiticicai, C. orientale, C. papachibe, C. pterostictum Gomes, C. rachovii, C. serrano, C. schubarti, C. steindachneri Cope, $C$. timbuiense, C. vestigipinne, C. vidali, and C. zebra), and analfin rays ii,7-8 (vs. ii,6 in C. brevirostre and C. roesseli Géry).

Concerning congeners known to occur in northeastern Brazilian rivers, C. samurai further differs from $C$. bahiense by having the aperture of the pseudotympanum enclosed between ribs of the fifth and sixth vertebrae (vs. aperture surpassing the ribs of the fifth vertebra anteriorly and/or sixth vertebra posteriorly), presence of the parietal branch of the supraorbital canal (vs. absence), two series of teeth on the dentary (vs. one), and 7-11 premaxillary teeth (vs. 5-8); from C. bimaculatum by having 7-8 branched anal-fin rays (vs. 5-6), usually a higher number of lateral-line scales (34-37 vs.
32-34), one faded dark bar on the proximal half of the dorsalfin rays (vs. a conspicuous black bar at the proximal portion of the rays and a second faded bar on the distal portion), and absence of a blotch on the caudal peduncle, or blotch merged to the longitudinal bar (vs. a conspicuous elongated caudal blotch); from $C$. fasciatum and C. lagosantense by having ii,7-8 anal-fin rays (vs. iii,5-6).

Description. Morphometric data of the holotype and paratypes presented in Table 1. Body elongate and moderately compressed. Greatest body depth at vertical through dorsalfin origin. Dorsal profile convex from upper lip to vertical through nares, slightly convex from this point to end of occipital process, slightly convex or straight from this point to origin of dorsal-fin base, convex along dorsal-fin base, almost straight between end of dorsal-fin base and adipose fin, slightly concave from this point to origin of anteriormost dorsal procurrent caudal-fin ray. Ventral profile of head straight, except for the convex portion close to dentary symphysis, slightly convex from isthmus to pelvic-fin origin, straight from 
latter point to anal-fin origin, slightly concave from this point to origin of anteriormost ventral procurrent caudal-fin ray. Snout triangular in lateral view. Mouth subterminal, aligned or slightly lower than ventral edge of the orbit. Distal tip of maxilla barely reaching the vertical through anterior margin of orbit. Orbit approximately round, larger than snout length. Cheek thin, its depth approximately one third to one quarter of orbit diameter. Nares separated; anterior naris with raised margins; posterior naris considerably closer to orbit than to anterior naris and without skin flaps. Supraorbital elongated in dorsal view, medial margin slightly convex, abutting the frontal, and lateral margin straight; anterior and posterior tip similarly pointed. Parietal fontanel limited anteriorly by frontals. Parietal branch of supraorbital canal present, slightly surpassing frontal-parietal border or extending to one third of parietal. Orbithosfenoid slightly rectangular in lateral view, connected anteriorly to rhinosphenoid. Pterosphenoid foramen for ophthalmic nerve relatively small, formed by tunnel crossing pterosphenoid diagonally, bordered by bony crest that prevents direct lateral view of brain cavity through foramen.

Dentary teeth in two rows; outer series with 10(5), 11*(5), 12(4), or 13(1) teeth; anterior two to four teeth from symphysis usually tricuspid, posterior conical; teeth decreasing in size from symphysis; inner series with several minute conical teeth inserted on edge of replacement tooth trench. Premaxilla with single series of $7 *(4), 8(21), 9(11)$, or 10(1) conical teeth, decreasing in size from symphysis. Maxillary edentulous. Ectopterygoid with a single series of 7(1) or 10(2) conical teeth. Mesopterygoid teeth absent.

Scales cycloid; circulii absent on posterior field of scales located immediately below $10^{\text {th }}$ scale of lateral line, 6 to 12

Table 1. Morphometric data of holotype and paratypes of Characidium samurai $(n=40)$. The range includes the holotype. $\mathrm{SD}=$ standard deviation.

\begin{tabular}{|c|c|c|c|c|}
\hline & Holotype & Range & Mean & SD \\
\hline Total length (mm) & 57.6 & $33.0-57.6$ & - & - \\
\hline Standard length (mm) & 46.6 & $20.8-46.6$ & - & - \\
\hline \multicolumn{5}{|c|}{ Percents of standard length } \\
\hline Depth at dorsal-fin origin & 26.2 & $23.0-28.5$ & 26.1 & 1.3 \\
\hline Depth at anal-fin origin & 18.9 & $16.0-20.3$ & 18.3 & 1.1 \\
\hline Caudal-peduncle depth & 12.2 & $9.3-13.4$ & 12.0 & 0.9 \\
\hline Caudal-peduncle length & 19.7 & $16.4-21.7$ & 18.5 & 1.1 \\
\hline Snout to dorsal-fin origin & 47.6 & $46.9-51.8$ & 49.6 & 1.2 \\
\hline Snout to pectoral-fin origin & 24.9 & 24.6-29.5 & 26.4 & 1.3 \\
\hline Snout to pelvic-fin origin & 51.3 & $50.0-54.9$ & 52.4 & 1.2 \\
\hline Snout to anal-fin origin & 74.9 & $74.0-77.6$ & 76.0 & 1.0 \\
\hline Anal-apex distance & 90.6 & 89.2-94.2 & 92.1 & 1.3 \\
\hline Body width & 10.7 & 10.6-14.5 & 11.9 & 0.8 \\
\hline Head length & 25.1 & $24.9-29.0$ & 26.6 & 1.1 \\
\hline \multicolumn{5}{|c|}{ Percents of head length } \\
\hline Horizontal eye diameter & 28.2 & $28.0-33.7$ & 30.5 & 1.7 \\
\hline Snout length & 23.9 & 21.9-26.1 & 24.0 & 1.1 \\
\hline Snout to maxillary tip & 26.5 & 23.2-27.8 & 25.4 & 1.1 \\
\hline Anterior naris to orbit & 12.0 & $8.5-14.0$ & 11.1 & 1.2 \\
\hline Posterior naris to orbit & 5.1 & $2.6-5.2$ & 3.9 & 0.8 \\
\hline Cheek depth & 9.4 & $5.7-10.3$ & 7.8 & 1.2 \\
\hline Least interorbital width & 24.8 & 20.0-26.5 & 23.6 & 1.9 \\
\hline
\end{tabular}

radii present. Lateral line complete, perforated scales 34(6), $35(28), 36 *(5)$, or $37(2)$; horizontal scale rows above lateral line $4 *(40)$; horizontal scale rows below lateral line $4 *(40)$. Scales along middorsal line between supraoccipital and origin of dorsal fin $9(2), 10(16), 11 *(7)$ or 12(2) in single row or irregularly arranged (8). Scale rows around caudal peduncle $14 *(38)$. Isthmus completely scaled. Pseudotympanum present, represented by muscular hiatus at vertical through anterior portion of swimbladder and situated between ribs of the fifth and sixth vertebrae (see 'Remarks' for details).

Dorsal-fin rays ii,9(1), ii,9,i(2), iii,9(3) or ii,10*(33); distal margin of dorsal fin rounded. Adipose fin present. Pectoral-fin rays highly variable, ii,9,i(2), iii,5,iii(4), iii,6,ii(1), iii,7,ii(3), iii,8,i*(19), iii,8ii,(1), or iii,9,i(2); first and second branched pectoral-fin rays longest; posterior tip of pectoral fin not reaching pelvic-fin insertion. Pelvic-fin rays i, $7, i^{*}(40)$; second to fourth branched pelvic-fin rays longest; posterior tip of pelvic fin not reaching anal-fin origin. Anal-fin rays ii, $7 *(39)$ or ii, $8(1)$; posterior margin of anal fin varying from rounded to straight; fin elements (i.e., adnate rays) on last pterygiophore $2 *(16)$. Caudal-fin rays i, $8,8, i^{*}(2), i, 9,8, i^{*}(35)$, or i, $9,9, i(1)$. Dorsal procurrent caudal-fin rays $8(3)$; ventral procurrent caudal-fin rays $7(1)$ or $8(2)$.

Total number of vertebrae 34(1) or 35(2); precaudal vertebrae $18(1)$ or 19(2); caudal vertebrae 15(2) or 17(1). Supraneural bones 5(1) or 6(2), anterior to neural spine of fifth centrum. Epural bones 2(3). Uroneural bones 1(3). Branchiostegal rays 4(3); 2 or 3 connected to anterior ceratohyal, 1 connected to the cartilage between anterior and posterior ceratohyals, none or 1 connected to posterior ceratohyal.

Color in alcohol. Ground color of head and body pale yellow, with dorsum darker (Fig. 1a). Small melanophores concentrated over dorsal and anterior portion of head; superior half of maxilla, upper and lower lip distinctly darker. Dark band extending from snout to posterior margin of opercle. Ventral half of head clear, with sparse small melanophores, except by the dark lower lip. Scales of dorsal half of body with melanophores concentrated on posterior margin of scales, resulting in somewhat reticulated aspect. Dorsal half of body with 8 to 10 inconspicuous dark vertical bars, broader dorsally (usually 3 scales wide), merged ventrally with dark longitudinal band. Most specimens with vertical bars inconspicuous and merged to one another resulting in dark and somewhat homogeneous dorsal half of body. Broad dark band (1.5 or 2 scales wide) with straight borders extending from rear of opercle to end of caudal peduncle. Dark humeral blotch on rear of opercle merged to longitudinal band and somewhat inconspicuous; in some specimens visible as a rounded or somewhat triangular and vertically elongated blotch. Ventral half of body yellowish, without dark bars or spots. Some specimens with concentrations of dark chromatophores on 
posterior border of scales situated on the row immediately below dark longitudinal stripe but not forming stripes or blotches. Ventral area located between pelvic and anal fin origins with dark narrow stripe, usually conspicuous on specimens of $30 \mathrm{~mm}$ SL or smaller and faded on larger specimens. Fins with melanophores sparsely distributed on border of rays, more concentrated on distal half. Dorsal fin with faded dark band below midlength of rays. Small dark round spot near base of middle caudal-fin rays. Adipose fin somewhat dark, with sparse melanophores.

Color in life. Ground color of dorsal half of body grayish and ventral half whitish (Fig. 1b). Dark lateral band extending from snout tip to end of caudal peduncle; band usually poorly visible immediately after the fish capture but clearly conspicuous if the specimen is allowed to stay a few minutes alive in a container such as a plastic bag. Approximately ten inconspicuous dark vertical bars over dorsal half of body; bars larger dorsally and not extending beyond ventral border of dark longitudinal band. Ventral half of body without dark bars or spots. Yellow chromatophores sparsely distributed over opercle, infraorbitals, ventral half of iris, and area posterior to opercle. Fins yellowish.

Etymology. The name samurai is given to honor the Japanese warrior caste that provided the administrative and fighting aristocracy from the $11^{\text {th }}$ to the $19^{\text {th }}$ centuries. The samurais are known by their expertise in several kinds of martial arts. Currently, expertise in martial art is attested by the term "black belt", a condition inherent to that warrior caste. The name samurai was used herein in allusion to the conspicuous midlateral black band present in the new species. A noun in apposition.

Sexual dimorphism. No hooks on fins or other sexually dimorphic features were observed externally on the specimens that were examined.

Distribution. Characidium samurai is known from the rio das Almas and rio Vermelho basins, two small coastal river systems at the central coastal area of Bahia State, eastern Brazil (Fig. 2a). Extensive ichthyological collecting efforts in the main coastal rivers across Bahia in the last eight years have failed to yield samples of $C$. samurai from another river drainages, making it possible that the species is endemic to rio das Almas (Figs. 2b-c) and rio Vermelho basins (Fig. 2d).

Habitat and ecological notes. Characidium samurai was collected in clear water streams with water running over rocks, pebbles, sand and/or muddy bottoms, at altitudes ranging from 17 to $177 \mathrm{~m}$ a.s.l. in habitats characterized mainly by moderate water current. The riparian vegetation mainly comprises remnants of the Atlantic Forest, cocoa trees or cattle pasture. The rio do Peixe (a tributary of rio das Almas basin), the type locality and where most specimens were collected, is approximately $2 \mathrm{~m}$ wide, $1-2$ $m$ deep, and has a medium to fast water current, muddy substrate and grassy river borders (Fig. 2b). Characidium samurai was collected syntopically with Characidium aff. timbuiense, Awaous tajasica (Lichtenstein), Astyanax aff. bimaculatus (Linnaeus), Astyanax sp., Dormitator maculatus (Bloch), Geophagus sp., Gymnotus carapo Linnaeus, Hoplias malabaricus (Bloch), Leporinus bahiensis Steindachner, L. melanopleurodes Birindelli, Britski \& Garavello, Hypostomus sp., Parotocinclus sp., Poecilia reticulata Peters, Sycidium punctatum (Perugia), and Synbranchus marmoratus Bloch. The analysis of stomach contents of the three c\&s specimens revealed the presence of vascular plant fragments, Trichoptera (Hydroptilidae) larvae, adults of terrestrial insects (Hymenoptera: Formicidae and Orthoptera), and fragments of unidentified arthropods.

Remarks. The new species described herein apparently does not fit in any group of Characidium that has been previously proposed in the literature (e.g., Buckup \& Reis, 1997; Buckup \& Hahn, 2000; Graça \& Pavanelli, 2008) and does not share any synapomorphy that was hypothesized by Buckup (1993a) to any particular subgroup of Clade C. Although C. samurai externally resembles C. lanei, a member of clade C4 of Buckup (1993a), particularly by sharing a broad dark longitudinal band, the new species has the parietal branch of the supraorbital canal, the absence of which is a diagnostic feature of clade C4. Characidium samurai also does not share the two synapomorphies of the species included in the $\mathrm{C} 4$ clade that were previously proposed by Buckup \& Reis (1997) and Buckup \& Hahn (2000): an increased number of vertical bars on the sides of the body and an absence of the inner row of dentary teeth.

Various populations of Characidium that have been sampled in rivers draining Bahia State are usually left unidentified or are tentatively identified as species described to nearby drainages, accompanied by the terms "affinis" or "confer" (Characidium sp., C. cf. bahiense, C.cf. bimaculatum, and C. aff. timbuiense, e.g., Santos \& Caramaschi, 2007, 2011; Sarmento-Soares et al., 2008, 2009; Cetra et al., 2010; Burger et al., 2011). These tentative identifications are actually indicative of the current poor taxonomical knowledge about the Characidium species in that region, which very likely, harbors several undescribed species of the genus. Thus, the only Characidium species that can be considered to be reliably documented for the coastal river drainages of Bahia State is C. bahiense, described from Arembepe, at the northern coastal area of the state. Furthermore, examination of museum specimens that were previously identified as $C$. bimaculatum from Bahia State led to doubts about the occurrence of that species in those rivers (see 'Comparative material'). Considerable further taxonomical work is necessary to unveil the diversity of the genus Characidium occurring at the rivers from northeastern Brazil. 

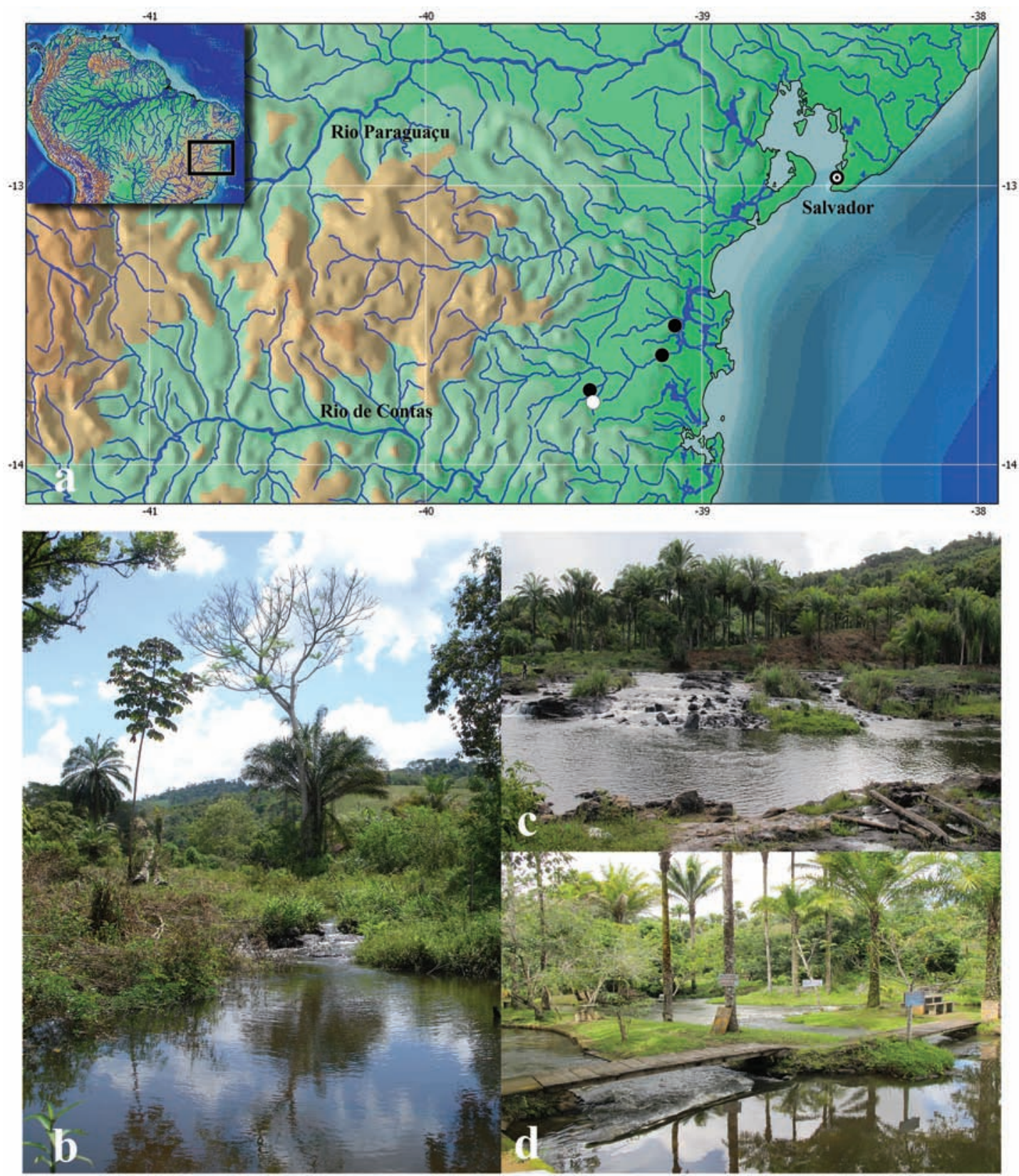

Fig. 2. Distribution and streams inhabited by Characidium samurai: (a) map of distribution of the new species (white dot represents the type locality), (b) type locality, Piraí do Norte, rio do Peixe, tributary of rio das Almas, (c) Nilo Peçanha, rio das Almas, and (d) Taperoá, rio Sarapuí, tributary of rio Vermelho.

Géry (1977: 127) called attention to the absence of a humeral spot in $C$. bahiense, being replaced by a humeral hiatus. The presence of a hiatus within the muscles in the region over the anterior chamber of the swimbladder (the pseudotympanum) is well known in diverse groups of Characiformes (e.g., Cheirodontinae: see Malabarba, 1998; Characinae: see Mattox \& Toledo-Piza, 2012). Although some authors questioned the homology of the pseudotympanum in different lineages of Characiformes
(Böhlke, 1953; Malabarba, 1998), recent studies revealed that the structure occurs in many species of the remaining orders of the Otophysi (Moreira et al. 2007) and is possibly plesiomorphic within the Characiformes (Mattox \& ToledoPiza, 2012). Details of the pseudotympanum form and position have been used to diagnose species (Menezes, 2006) and define evolutionary lineages among South American characiforms (Malabarba, 1998). Particularly in Characidium, in addition to $C$. bahiense, the presence of the 
pseudotympanum was reported in the description of some species and in phylogenies that included a few species of the genus (e.g., Graça et al., 2008; Silveira et al. 2008; Mirande, 2010; Peixoto \& Wosiacki, 2013).

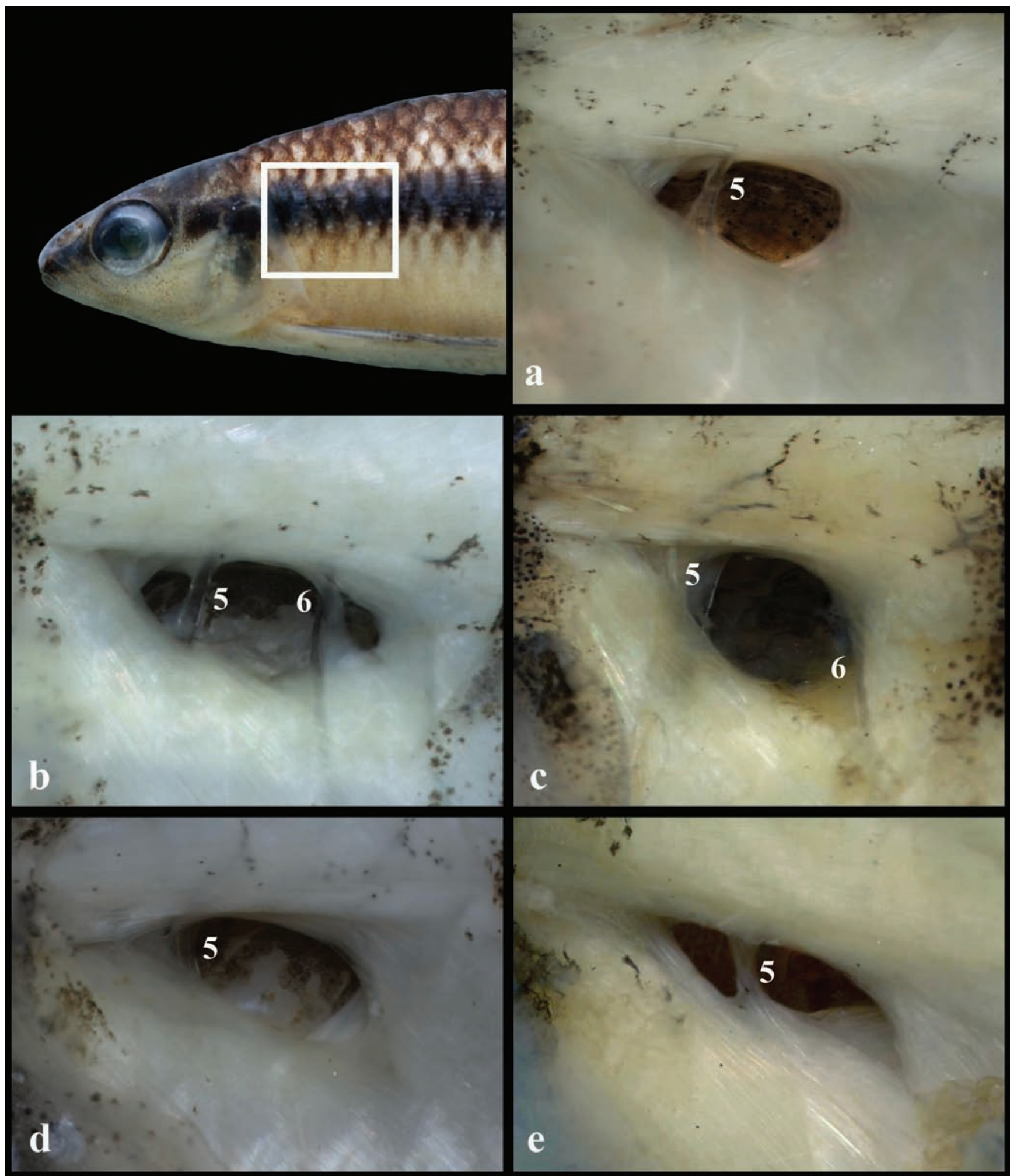

Fig. 3. Pseudotympanum of: (a) Characidium bahiense UFBA 3470, $23.2 \mathrm{~mm}$ SL, (b) C. bahiense UFBA 7167, $25.4 \mathrm{~mm}$ SL, (c) C. samurai, paratype, UFBA 7259, $41.2 \mathrm{~mm} \mathrm{SL}$, (d) C. bimaculatum UFBA 3829, $29.5 \mathrm{~mm}$ SL, and (e) Characidium timbuiense UFBA 6506, $32.8 \mathrm{~mm}$ SL. Numbers correspond to vertebrae associated with pleural ribs. Left side, anterior to left. Overlying skin, adipose tissue and lateral-line nerve removed. 
The pseudotympanum of three species of Characidium that occur in the northeastern Brazilian drainages ( $C$. bahiense, C. bimaculatum, and C. samurai), in addition to $C$. timbuiense was examined herein. The muscular hiatus in these species is mainly situated between ribs of the fifth and sixth vertebrae. However, these hiatuses are somewhat variable regarding their positions in relation to the cited ribs, size, form, and extension of the apertures (Fig. 3). The pseudotympanum of C. bahiense is usually easily observed without skin removal and appears as a dark area corresponding to the muscular hiatus on the humeral region (see Géry 1977: figs. 4a-b). The species possesses a well-developed pseudotympanum, with most of the hiatus situated between ribs of the fifth and sixth vertebrae, but with small opening anterior to rib of fifth (Fig. 3a) or small openings anterior to rib of fifth and posterior to rib of sixth vertebra (Fig. 3b). Thus, part of the fifth and sixth vertebrae ribs are usually completely embedded within the aperture and the overall structure of $C$. bahiense is comparatively larger than in the other species cited. The presence of a small muscle hiatus anterior to the fifth vertebra was previously cited for various taxa (Malabarba, 1998; Mattox \& Toledo-Piza, 2012). More recently, a pseudotympanum with aperture extending both anterior to the fifth and posterior to the sixth vertebrae was described by Jerep \& Vari (2013) for the African distichodontid Hemigrammocharax rubensteini Jerep \& Vari. These features represent an obvious convergence given the phylogenetic distance between Characidium and the cited species.

Distinct from C. bahiense, the pseudotympanum of C. samurai and C. bimaculatum has a unique rounded aperture, completely inserted between the ribs of the fifth and sixth vertebrae (Figs. 3c-d, respectively). Reduction of musculature that is anterior to the fifth vertebra is observed in some specimens of the latter two species, but the area is not completely naked, and the swimbladder is not visible through it. In turn, the pseudotympanum of C. timbuiense is distinctly narrower compared to the structures described above and is represented by an elongated hiatus with pointed anterior and posterior margins (Fig. 3e). In fact, the aperture of the pseudotympanum in C. timbuiense, slightly surpass the rib of the fifth vertebra anteriorly, resulting in a small opening anterior to that rib. Furthermore, the orientation of the rib of the fifth vertebra relative to the opening is distinctly inclined, in contrast to the more vertical orientation in the cited congeners. Characidium timbuiense also have a thicker hypaxial musculature around the pseudotympanum, resulting in apertures somewhat deeper than that of the congeners examined. The opposite condition is observed in C. bahiense, with a thin hypaxial musculature and a pseudotympanum apparently shallowly situated. Commonly, taxonomic studies including Characidium provide no information about the pseudotympana except in a few cases, which usually only discuss the presence or absence of the structure. The study performed here, although including only four species, revealed interesting variation regarding the size, shape, number of apertures, and degree of rib exposure.

Comparative material examined. All from Brazil and specimens alcohol-preserved (except when noted). Characidium alipioi: MNRJ 5550, holotype, $50.0 \mathrm{~mm}$ SL, Rio de Janeiro, rio Paraíba do Sul basin; MNRJ 5551, paratype, $51.0 \mathrm{~mm}$ SL; MNRJ 5552, paratype, 48.3 mm SL; MNRJ 5553, paratype, 45.0 mm SL. MZUSP 112331, 6, 50.3-72.3 mm SL, São Paulo, rio Paraíba do Sul basin. Characidium bahiense: MZUSP 8940, holotype, 16.0 mm SL, Bahia, Arembepe; MZUSP 8923, paratype, 18.7 mm SL; MZUSP 8924, paratype, 21.5 mm SL. UFBA 2882, 6, 18.4-24.0 mm SL; UFBA 2886, 4, 19.1-22.0 $\mathrm{mm}$ SL, Bahia, rio Inhambupe basin. UFBA 4348, 18, 18.0-24.1 mm SL, Bahia, rio Paraguaçu basin. UFBA 4685, 20, 17.2-22.2 mm SL, Bahia, rio Capivara basin. UFBA 7167, 23, 3 c\&s, 21.1-26.0 mm SL, Bahia, rio Itapicuru basin. Characidium bimaculatum: MNRJ 21249, 14, 20.5-41.4 mm SL, Ceará, rio Curu basin. MNRJ 4925, 1, 25.5 mm SL; MNRJ 4928, 1, 28.7 mm SL, Ceará, rio Salgado basin. MNRJ 4959, 1, 23.2 mm SL; MNRJ 4964, 1, 28.8 mm SL. MNRJ 4975, 1, 29.4 mm SL, Ceará, rio Cotuí. MZUSP 1107779, 8, 29.4-24.3 mm SL, Paraíba, rio Acaraú basin. UFBA 3829, 6, 1 c\&s, 22.5-30.8 $\mathrm{mm}$ SL, Paraíba rio Piranhas basin. Characidium cf. declivirostre: MZUSP 97137, 1, 35.4 mm SL, Pará, rio Xingu basin. MZUSP 82084, 2, 44.5-46.5 mm SL, Mato Grosso, rio Juruena basin. Characidium fasciatum: MZUSP 39676, 15, 32.7-36.4 mm SL, Minas Gerais, rio São Francisco basin. MZUSP 49261, 6, 22.2-35.0 mm SL, Bahia, rio Paraguaçu basin. Characidium gomesi: MZUSP 73193, 47, 25.8-32.0 mm SL, Minas Gerais, rio Paranaíba basin. MZUSP 88440, 3, 29.5 42.8 mm SL, São Paulo, rio Corumbataí. Characidium grajahuensis: MNRJ 3855, holotype (snout damaged, precise measurement currently not possible), Rio de Janeiro, Grajaú. Characidium hasemani: MZUSP 91785, 4, 44.0-58.0 mm SL, Mato Grosso, rio Xingu basin. Characidium heirmostigmata: MZUSP 97738, holotype, 34.6 mm SL, Paraná, rio Paraná basin. Characidium interruptum: MZUSP 58992, 1, 30.9 mm SL, Rio de Janeiro, rio São João basin. Characidium japuhybense: MNRJ 5194, holotype (snout damaged, precise measurement currently not possible), Rio de Janeiro, Angra dos Reis. Characidium lagosantense: MNRJ 3852, holotype (snout damaged, precise measurement currently not possible), Minas Gerais, rio São Francisco basin. MNRJ 18108, 71, 11.2-31.2 mm SL, Minas Gerais, rio São Francisco basin. Characidium lanei: MNRJ 6185, holotype, $40.8 \mathrm{~mm}$ SL, São Paulo, rio Ribeira do Iguape basin; MNRJ 9766, paratype, 36.2 mm SL. MNRJ 32884, 38, 20.9-36.4, São Paulo, rio Lajeado. MZUSP 69585, 7, 25.2-31.0 mm SL, São Paulo, rio Ribeira do Iguape basin. Characidium laterale: MZUSP 90204, 2, 20.6-25.1 mm SL, Mato Grosso, rio Paraguai basin. MZUSP 96687, 80, 15.7-24.0 mm SL, Mato Grosso, rio Paraguai basin. Characidium lauroi: MNRJ 5529, holotype, $60.4 \mathrm{~mm} \mathrm{SL}$, Rio 
de Janeiro, rio Paraíba do Sul basin; MNRJ 5530, paratype, $56.8 \mathrm{~mm}$ SL. MZUSP 110359, 5, 31.1-45.9 mm SL, São Paulo, rio Paraíba do Sul basin. Characidium nupelia: MZUSP 87743, holotype, $29.0 \mathrm{~mm}$ SL, Mato Grosso, rio Paraguai basin. Characidium oiticicai: MNRJ 9480, holotype, $35.3 \mathrm{~mm}$ SL, São Paulo, rio Tietê basin. MZUSP 108640, 2, 37.4-38.1 mm SL, São Paulo, rio Tietê basin. Characidium cf. pteroides: MZUSP 85653, 81, 16.3-28.7 mm SL, Amazonas, rio Negro basin. Characidium pterostictum: MZUSP 43547, 15, 28.7$37.8 \mathrm{~mm}$ SL, Rio Grande do Sul, Mampituba system. Characidium rachovii: MZUSP 49163, 8, 25.9-34.2 mm SL, Rio Grande do Sul Lagoa dos Patos drainage. Characidium stigmosum: MZUSP 40804, holotype, $33.5 \mathrm{~mm}$ SL, Goiás, rio Tocantins basin. Characidium tenue: MZUSP 63803, 6, 31.0-42.2 mm SL, Rio Grande do Sul, rio Jacuí basin. Characidium timbuiense: MNRJ 4285, holotype, 51.8 mm SL, Espírito Santo, rio Timbuí basin. MNRJ 4284, paratype, 56.9 mm SL; MNRJ 4292, paratype, $53.1 \mathrm{~mm}$ SL; MNRJ 4315, paratype, $48.8 \mathrm{~mm}$ SL. UFBA 6506, 6, $1 \mathrm{c \& s,} \mathrm{27.9-44.0} \mathrm{mm} \mathrm{SL,}$ Espírito Santo, rio Timbuí basin. Characidium vidali: MNRJ 9757 , holotype, $47.8 \mathrm{~mm}$ SL, Rio de Janeiro, rio Soberbo. Characidium xavante: MZUSP 87745, paratypes, 20, 13.9-22.7 mm SL, Mato Grosso, rio Xingu basin. Characidium cf. zebra: MZUSP 92910, 7, 26.5-29.0 mm SL, Amazonas, rio Negro basin. MZUSP 98203, 11, 26.5-31.4 mm SL, Mato Grosso, rio Xingu basin. Characidium sp.: MNRJ 22424, 21, 27.8-42.3 mm SL; MNRJ 23756, 2, 22.2-25.6 mm SL; MNRJ 23758, 1, 30.1 mm SL, Bahia, rio Jequiriçá basin. MNRJ 23752, 3, 22.2-24.1 mm SL; MNRJ 23755, 1, 24.6 mm SL; MNRJ 23757, 2, 21.2-22.5 mm SL; MNRJ 23764, 1, 20.3 mm SL, Bahia, rio Paraguaçu basin. MZUSP 100772, 11, 23.4-34.4 mm SL, Bahia, rio Paraguaçu basin. MZUSP 112697, 3, 42.6-52.6, Bahia, rio Pardo basin. MZUSP 112736, 18, 26.3-48.8 mm SL; MZUSP 112738, 19, 28.1-53.9 mm SL, Bahia, rio Almada basin.

\section{Acknowledgments}

For critical review of the manuscript, we thank Adolfo R. Calor, José L. Birindelli, Marcelo Melo, and one anonymous reviewer. For loans or permission to examine comparative material we thank Marcelo R. Britto (MNRJ) and Osvaldo T. Oyakawa (MZUSP). We are grateful to Alexandre B. A. Góes, Fernando C. Dagosta, José L. Birindelli, Marina V. Loeb, Osvaldo T. Oyakawa, Rafael Burger, and Túlio F. Teixeira for their help during field expeditions. Funding for fieldwork, in which the new species were collected, was provided by CNPq (grant \#476449/2007-3) and by PROAP/ PPGDA-UFBA. The present contribution was also supported by the project South American Characiformes Inventory (FAPESP 2011/50282-7). Photographs of live specimens were produced by Osvaldo T. Oyakawa. Photographs of pseudotympana were produced by Rafael O. Abreu. We also thank Adolfo R. Calor for the identification of insects of the stomach contents. Permission for collecting specimens was granted by IBAMA.

\section{Literature Cited}

Böhlke, J. E. 1953. Studies on fishes of the family Characidae. A review of the genus Microschemobrycon with descriptions of two new species. Annals and Magazine of Natural History (Series 12), 6: 841-849.

Buckup, P. A. 1992. Redescription of Characidium fasciatum, type species of the Characidiinae (Teleostei, Characiformes). Copeia, 1992: 1066-1073.

Buckup, P. A. 1993a. Phylogenetic interrelationships and reductive evolution in Neotropical characidiin fishes (Characiformes: Ostariophysi). Cladistics, 9: 305-341.

Buckup, P. A. 1993b. Review of the characidiin fishes (Teleostei: Characiformes), with descriptions of four new genera and ten new species. Ichthyological Exploration of Freshwaters, 4: 97-154.

Buckup, P. A. 2003. Family Crenuchidae (South American darters), p. 87-95. In: Reis, R. E., S. O. Kullander \& C. J. Ferraris Jr. (Eds.). Cheek list of the freshwater fishes of South and Central America. Porto Alegre, Edipucrs.

Buckup, P. A. \& L. Hahn. 2000. Characidium vestigipinne: a new species of Characidiinae (Teleostei, Characiformes) from Southern Brazil. Copeia, 2000: 150-155.

Buckup, P. A. \& R. E. Reis. 1997. Characidiin genus Characidium (Teleostei, Characiformes) in southern Brazil, with description of three new species. Copeia, 1997: 531-548.

Burger, R., A. M. Zanata \& P. Camelier. 2011. Estudo taxonômico da ictiofauna de água doce da bacia do Recôncavo Sul, Bahia, Brasil. Biota Neotropica, 11: 273-290.

Cetra, M., G. R. Rondineli \& U. P. Souza. 2011. Compartilhamento de recursos por duas espécies de peixes nectobentônicas de riachos na bacia do rio Cachoeira (BA). Biota Neotropica, 11: 87-95.

Cetra, M., L. M. Sarmento-Soares \& R. F. Martins-Pinheiro. 2010. Peixes de riachos e novas Unidades de Conservação no sul da Bahia. Pan-American Journal of Aquatic Sciences, 5: 11-21.

Géry, J. 1977. Notes on Certain Characoid Fishes (Order Cypriniformes) from Eastern and Southeastern Brazil. Bonner Zoologische Beiträge: 122-134.

Graça, W. J. \& C. S. Pavanelli. 2008. Characidium heirmostigmata, a new characidiin fish (Characiformes: Crenuchidae) from the upper rio Paraná basin, Brazil. Neotropical Ichthyology, 6: 53-56.

Graça, W. J., C. S. Pavanelli \& P. A Buckup. 2008. Two new species of Characidium (Characiformes: Crenuchidae) from Paraguay and Xingu basins, state of Mato Grosso, Brazil. Copeia, 2008: 326-332.

Jerep, F. \& R. P. Vari. 2013. New Species of Hemigrammocharax (Characiformes: Distichodontidae) from the Northwestern Congo River Basin. Copeia, 2013: 31-37.

Malabarba, L. R. 1998. Monophyly of the Cheirodontinae, characters and major clades (Ostariophysi: Characidae), Pp. 193-233. In: Malabarba, L. R., R. E. Reis, R. P. Vari, Z. M. S. Lucena \& C. A. Lucena (Eds.). Phylogeny and Classification of Neotropical Fishes. Porto Alegre, Edipucrs.

Mattox, G. M. \& M. Toledo-Piza. 2012. Phylogenetic study of the Characinae (Teleostei: Characiformes: Characidae). Zoological Journal of the Linnean Society, 165: 809-915.

Melo, M. R. S. 2001. Sistemática, filogenia e biogeografia do grupo Characidium lauroi Travassos, 1949 (Characiformes, Crenuchidae). Unpublished Dissertation, Museu Nacional, Rio de Janeiro, 55p.

Menezes, N. A. 2006. Description of five new species of Acestrocephalus Eigenmann and redescription of A. sardina and A. boehlkei (Characiformes: Characidae). Neotropical Ichthyology, 4: 385-400. 
Mirande, J. M. 2010. Phylogeny of the family Characidae (Teleostei: Characiformes): from characters to taxonomy. Neotropical Ichthyology, 8: 385-568.

Moreira, C. R., M. I. Landim \& F. Di Dario. 2007. Pseudotympanum, an additional synapomorphy for Otophysi (Teleostei, Ostariophysi). Joint Meeting of Ichthyologists and Herpetologists, Saint Louis.

Netto-Ferreira, A. L., J. L. O. Birindelli \& P. A. Buckup. 2013. A new miniature species of Characidium Reinhardt (Ostariophysi: Characiformes: Crenuchidae) from the headwaters of the rio Araguaia, Brazil. Zootaxa, 3664: 361-368.

Peixoto, L. A. W. \& W. Wosiacki. 2013. A New Species of Characidium (Characiformes: Crenuchidae) from the Lower Amazon. Copeia, 2013: 52-57.

Santos, A. C. A. \& E. P. Caramaschi. 2007. Composition and Seasonal Variation of the Ichthyofauna from Upper Rio Paraguaçu (Chapada Diamantina, Bahia, Brazil). Brazilian Archives of Biology and Technology, 50: 663-672.

Santos, A. C. A. \& E. P. Caramaschi. 2011. Temporal variation in fish composition and abundance in a perennial tributary of the rio Paraguaçu, a little-known drainage in the Brazilian semi-arid region. Neotropical Ichthyology, 9: 153-160.

Sarmento-Soares, L. M. \& R. F. Martins-Pinheiro. 2009. A fauna de peixes na bacia do Rio do Frade e microbacias vizinhas, extremo sul da Bahia. Boletim do Museu de Biologia Professor Mello Leitão, 26: 25-46.

Sarmento-Soares, L. M., R. Mazzoni \& R. F. Martins-Pinheiro. 2007. A fauna de peixes na bacia do Rio Peruípe, extremo Sul da Bahia. Biota Neotropica, 7: 291-308.
Sarmento-Soares, L. M., R. Mazzoni \& R. F. Martins-Pinheiro. 2008. A fauna de peixes dos Rios dos Portos Seguros, extremo sul da Bahia, Brasil. Boletim do Museu de Biologia Professor Mello Leitão, 24: 119-142.

Sarmento-Soares, L. M., R. Mazzoni \& R. F. Martins-Pinheiro. 2009. A fauna de peixes na bacia do Rio Jucuruçu, leste de Minas Gerais e extremo Sul da Bahia. American Journal of Aquatic Sciences, 4: 193-207.

Silveira, L. G. G., F. Langeani, W. J. Graça, C. S. Pavanelli \& P. A. Buckup. 2008. Characidium xanthopterum (Ostariophysi: Characiformes: Crenuchidae): a new species from the Central Brazilian Plateau. Neotropical Ichthyology, 6: 169-174.

Taylor, W. R. \& G. C. Van Dyke. 1985. Revised procedures for staining and clearing small fishes and other vertebrates for bone and cartilage study. Cybium, 9: 107-109.

Weitzman, S. H. \& L. R. Malabarba. 1999. Systematics of Spintherobolus (Teleostei: Characidae: Cheirodontinae) from eastern Brazil. Ichthyological Exploration of Freshwaters, 10: 1-43.

Submitted September 27, 2013 Accepted March 10, 2014 by George Mattox Published June 30, 2014 